\title{
Comparison Analysis Of Tax Amnesty Implementation In Indonesia And Other Countries
}

\author{
Desy Farina*, Ghulam Fathul Amri*, Prianto Budi Saptono** \\ * Graduate Student, Institut STIAMI Jakarta \\ ${ }^{* *}$ Lecturer, Institut STIAMI Jakarta \\ DOI: 10.29322/IJSRP.11.08.2021.p11608 \\ http://dx.doi.org/10.29322/IJSRP.11.08.2021.p11608
}

\begin{abstract}
Tax revenue is a very vital thing in a country. However, it cannot be denied that there are parties who are taxpayers who try to avoid this obligation. Therefore, a country tries to pursue the tax debts of taxpayers in its country. One of the methods used to collect unpaid taxes is by means of a tax amnesty. The purpose of writing this paper is to map the countries that have implemented the program and how they got the results. The writing method used is descriptive Qualitative by using library research as a source of material. From the research that has been done, it is found that tax amnesty that is too frequent will have a negative impact on the behavior of taxpayers. Predictable tax amnesty will keep tax evaders waiting until future tax amnesty provides them with the best tax rates. However, it cannot be denied that the tax amnesty program also contributes significantly to state revenue which is beneficial for the development of the country.
\end{abstract}

Index Terms- Tax Amnesty, Taxpayer, Tax Payable

\section{INTRODUCTION}

$\mathrm{T}$ he fiscal and taxation systems, especially in areas such as public debt, inflation, fiscal deficits, income distribution, and economic stability greatly affect a country's macroeconomic policies and sustainable growth (MA Ibrahim, Myrna, Irawati, \& Kristiadi, 2017, p. 220 ). Tax amnesty programs have been widely used by many governments as part of their fiscal programs (Alm, Martinez-Vazquez, \& Wallace, 2009, p. 235). This is because there will always be people who run away from tax obligations as long as there is a tax collection in a country (Leenders, Lejour, Rabaté, \& Maarten, 2020, p. 2).

Tax amnesty is an opportunity provided by the state to tax arrears within a certain time they are required to fulfill their tax obligations including interest and penalties related to the previous tax period or a certain period without fear of criminal penalties (Andrian, 2016, p. 30). Tax Amnesty has a goal to increase state revenues and also to increase the number of taxpayers who comply and voluntarily pay taxes in the future (Trifani, 2018, p. 20).

This paper aims to conduct a systematic review of the literature that discusses the application of tax amnesty in several countries including Indonesia. This paper is expected to comprehensively contribute to the discipline of taxation by describing and analyzing the application of tax amnesty in various countries.

\section{IDENTIFY, RESEARCH, AND COLLECT IDEA}

\section{WRITING METHOD}

The method of writing this paper uses a qualitative method with a library review mechanism (Tukina, 2017, p. 272). The objective summary is referred to as a literature review, thoroughly by providing a critical analysis of the relevant research literature available on topics that are relevant to the topic being discussed or studied.

Literature Search Strategy

Papers on the application of tax amnesty in the world are collected from databases available on the internet, especially in the form of published scientific journals. As a strategy in the search used the keyword "tax amnesty" and the names of countries as the main subject title, title, abstract, keywords, and text words. Thus, there are a number of references that can be used and referenced in this paper. Due to the inadequacy of academic texts related to the application of tax amnesty in foreign countries, the researchers then searched for news and articles discussing tax amnesty that were available online. The same keywords and methods were used to search for articles discussing tex amnesty.

Guide Development

Indicators such as existing tax compliance, possible changes in law enforcement, eligibility, coverage, incentives, and duration the authors use to evaluate the implementation of the tax amnesty program in the specific countries discussed in this paper. Whether the application of tax amnesty in these countries succeeds or fails is also the author of the analysis. In addition, the factors that are the 
source of the achievement and failure of the tax amnesty program in the countries mentioned above are also investigated by the authors.

Selection of Articles for Review

Articles on the implementation of tax amnesty programs in countries that implement tax amnesty programs are identified and selected in the literature search process to be used as references in the writing carried out.

\section{THEORETICAL BASIS}

In order to implement the tax amnesty program properly, the government must conduct an assessment of the existing tax compliance conditions, prospects for changes in law enforcement, feasibility, scope, incentives and timeframe before implementing the planned tax amnesty program. The main factor as a determinant of the success of Tax Amnesty is the awareness and honesty of the community, especially Individual Taxpayers (WPOP). Therefore, the Government must first examine the existing conditions to see the feasibility of applying the tax amnesty. (Suryandari, 2017, p. 65).

A comprehensive study of tax regulations by the Government must also be carried out. This is so that it becomes the legal basis so that every action taken by the state is not easily sued by the parties who feel aggrieved by the existence of the program. Eligibility of tax amnesty is very important for the government to do. This is because the tax amnesty also targets those who are already in the role of taxation, apart from usually not only being addressed to prospective taxpayers who do not play a role. This program is applied to both domicile and non-domicile residents because it will affect the income collected from this program, so determining eligibility is very important to do.

In the tax amnesty program, determining the type of tax to be included must be carried out by the Government clearly and firmly. Personal income tax, corporate income tax, sales and use tax, and property tax are types of taxes that can be applied in a tax amnesty program. Amnesty literally means forgiveness. Therefore, the amount of unpaid taxes, interest, and penalties that will be forgiven through the tax amnesty program must be clearly detailed by the government. Tax amnesty either temporary or permanent, It is possible to obtain for policy makers. It is also possible for the government to implement a temporary tax amnesty program. The tax amnesty program generally takes place within a certain period of time, generally running for 2 months to 1 year (Safri, 2015, p. 107).

\section{STUDIES AND FINDINGS}

Based on the study conducted, the following are the results of the analysis of the implementation of tax amnesty in several countries: India

The tax amnesty program in India has been carried out with too much intensity so that it is part of the climate of weakening enforcement of income tax regulations (Safri, 2015, p. 116). The tax amnesty program in India was carried out in 1951, 1965, 1975, 1975, 1980, 1985, 1986, 1991, 1997, 2013 and most recently in 2016 (Purnomolastu, 2017, p. 82). In order to reduce the black economy, the 1997 tax amnesty program or called the Voluntary Income Disclosure Scheme (VDIS) was proposed. for each party this program targets corporations and individuals who charge a $35 \%$ rate and a $30 \%$ tax rate to legitimize their assets without retrospective penalties.

Gross domestic product of $3.6 \%$ from $3 \%$ or less in the previous 5 years was successfully increased through the 1997 tax amnesty program. More than 350,000 individuals and several companies were successfully withdrawn from disclosing their undisclosed income through the VDIS program. In 1997 the Supreme Court of India then ruled that the Indian government was not allowed to offer a tax amnesty scheme after 1997 (Huda \& Hernoko, 2017, p. 59). This happens on the grounds that the tax amnesty program punishes compliance and genuine taxpayers and at the same time encourages guilty tax violators.

From 1975 to 1976 India improved its trade balance from -286 million to +787 million US Dollars which shows how drastic the changes in its economy are (bose, 2010). And in the end the amnesty in India in 1997 was a success to be reckoned with. The Voluntary Disclosure of Income Scheme (VDIS' 97) program accounts for about 20 percent of the annual gross tax revenue (Andrian, 2016, p. 63).

In June-September 2016 the latest second Tax amnesty was introduced and managed to attract 64,275 declarations which resulted in Rs. 294 billion and contributed quite a lot of government revenue at that time. In the 2016 Income Declaration Scheme, taxpayers are only required to pay $31 \%$ tax against the stipulated $45 \%$ tax. The last tax amnesty which lasted from December 2016 to March 2017 was later launched by the Government of India. During that period, taxpayers are required to pay undeclared income and have to pay taxes, additional fees, and penalties in total to $49.9 \%$.

Indonesia

In the context of taxation, Indonesia is also experiencing very serious and complex tax problems, this is similar to what happened in India. The tax amnesty program in 1964, 1984 and 2008 was launched in Indonesia. However, all of these tax amnesty programs failed due to weak law enforcement problems. The third tax amnesty managed to raise Rp 7.46 trillion from 5,635,128 people, but the amount collected was lower than the target of the Indonesian tax office.

Indonesia again launched tax amnesty on July 1, 2016 to March 2017, after three tax amnesty programs were launched in 1964 , 1984 and 2008. Since the Sunset Policy Program was implemented throughout 2008 it has succeeded in increasing the number of new NPWPs by 5,653,128 NPWPs, increasing the annual SPT as many as 804,814 SPT and an increase in income tax revenues of Rp7.46 trillion. The number of NPWP for individuals is 15.07 million, NPWP for treasurers is 447,000, and NPWP for legal entities is 1.63 million. So the total is 17.16 million (Dewi, 2016, p. 98).

This publication is licensed under Creative Commons Attribution CC BY

http://dx.doi.org/10.29322/IJSRP.11.08.2021.p11608

WwW.ijsrp.org 
ISSN 2250-3153

In order to increase tax revenues for 2016-2017, improve future tax compliance, return of capital, transition to a new tax system and national reconciliation. Repatriation is the first objective of the tax amnesty in Indonesia. It is the purpose of implementing tax amnesty in Indonesia. Article 2 paragraph (2) letter a and the general explanation section of the tax amnesty law. Funds flowing from abroad to Indonesia will improve the Indonesian economy (Safri, 2015, p. 108).

Revenue from the tax amnesty alone amounted to $109.05 \mathrm{~T}$ in 2016 , or contributed $13 \%$ of all income tax revenues obtained. In 2017 the tax amnesty was only valid for 1 period, namely January 1, 2017 to March 31, 2017. Within 3 months, the tax amnesty revenue was 25.5T or contributed 3.25\% of all income tax revenues in 2017 (Pravasanti, 2018, p. 90).

There is a study that shows that accrual earnings management has a positive effect on the possibility of company owners to participate in the tax amnesty program in the context of the case in Indonesia (Geraldina \& Jasmine, 2019, p. 26). In terms of accounting, the tax amnesty standard is in the form of additional assets and repatriated funds in the form of bonds and shares which are named Statement of Financial Accounting Standards (PSAK) 70, Financial Accounting Standard 70 issued by the Financial Accounting Standards Board (DSAK), Financial Accounting Standards Board (Natania) \& Davianti, 2018, p. 1).

Pakistan

Complete information about the history of tax amnesty in Pakistan is also not available in large quantities. Or in other words only available in very limited quantities. Between 7 December and 26 December 2016 The latest tax amnesty in Pakistan was carried out recently. The Pakistani government only targets the tax amnesty program to the property sector. Pakistak's tax amnesty can be said to have failed because only 1919 transactions were made and it was only able to raise funds of Rs. 50 million (\$0.0004 billion) through this program (M. A. Ibrahim et al., 2017, p. 223).

The Pakistan Federal Revenue Council then offered a more general tax amnesty in the future to cover all sectors and all residents and non-residents of Pakistan after taking lessons from the failure of the 2016 tax revenue. The tax structure in Pakistan has been destroyed due to the 2016 tax amnesty program. it has given real estate investors the privilege to pay taxes at a mere $3 \%$ rate. Instead, Pakistanis have to pay a maximum of $35 \%$ tax on their income and pay a $100 \%$ fine for late payments. This program directly penalizes honest taxpayers. In addition, the 2016 real estate tax amnesty program also gives real estate investors legal permission to whiten their black money. Besides that, it turns out that the tax amnesty has resulted in an increase in property prices in Pakistan due to the repatriation of black money to the property sector.

Netherlands

There are more than 28,000 tax evaders in the Netherlands. By investigating the distribution of tax evasion and its implications for the measurement of wealth inequality, data on tax evaders are obtained. The correction in offshore wealth has only a modest effect on the top wealth stocks. after amnesty participation there was a large and sustained increase in reported wealth of around $60 \%$. Combined with evidence of only modest improvements in the adoption of tax avoidance strategies, this suggests that amnesty participation can result in substantial public revenue gains (Leenders et al., 2020, p. 1). In this respect, the Netherlands is similar to Indonesia where Tax Amnesty contributes significantly to state revenue.

Tanzania

Motivated taxpayers and voluntary payments of basic tax obligations under the tax amnesty program have a significant positive effect on tax collection in Tanzania, namely by waiving 100 percent of interest, fines and penalties through the Tax amnesty program. Such findings indicate that the tax amnesty program has had a positive impact on tax collection in Tanzania. The findings also reveal that tax amnesty has increased tax collection. In addition, most of the taxpayers revealed that the tax amnesty program offers relief to taxpayers by only paying the basic tax, motivates taxpayers to pay taxes, and allows the basic tax obligations to be paid. installments over a certain period of time. Furthermore, the findings reveal that the tax amnesty program allows taxpayers to pay basic taxes voluntarily. The tax amnesty program faces a number of challenges, including the following; Most taxpayers choose to pay their debts through the amnesty program rather than through the regular taxation system, this prevents honest taxpayers from paying taxes on time and this is considered a reward for those who avoid complying with tax regulations. As for improving the tax amnesty program for effective debt collection, more education is needed to taxpayers about the tax amnesty program, how it works and its benefits for them, the program requires full support from the government and its organs. There must be a conducive policy to support the tax amnesty program and there must be a reliable tax amnesty infrastructure (F. P. Ibrahim, 2020, p. 56).

In addition, there are also research findings showing that tax amnesty has a positive impact on government tax revenues and tax compliance of large taxpayers, but has a negative impact on business income of large taxpayers. Therefore, it can be concluded that tax amnesty can effectively increase tax revenue and tax compliance among large taxpayers, but does not necessarily increase the income of large taxpayers. It is recommended that a good tax regime management, motivation for large taxpayers through tax reduction and appropriate tax education can foster a positive impact of tax amnesty among large taxpayers (Ahmed, 2020, p. vi).

South Africa

In the tax amnesty carried out in South Africa, incentives are given to attract taxpayers to participate in this program by eliminating fines and interest on taxes owed or paying a ransom at a low rate. For taxpayers who do not want to participate in this program, the government provides pressure or discomfort, for example by increasing the quantity and quality of tax audits, strategies for selecting the right investigation targets and transparency of investigation results as well as temporary tax penalties before the tax amnesty program is announced. South Africa has implemented the tax amnesty program three times, namely in 1995, 1996, 2003 (Safri, 2015, p. 115) and the last time South Africa issued a Volunteer Disclosure Program policy (Andrian, 2016, p. 7).

Kosovo

This publication is licensed under Creative Commons Attribution CC BY.

http://dx.doi.org/10.29322/IJSRP.11.08.2021.p11608

WwW.ijsrp.org 
Over the past 10 years the Republic of Kosovo has practiced tax amnesty twice. Most businesses that previously evaded taxes are now regular taxpayers after tax amnesty is shown by the available evidence. Even according to the results of a study concluded that the success of tax amnesty depends on the fulfillment of certain conditions such as;

- confidentiality of recipients of tax amnesty,

- The time to take advantage of the tax amnesty must be adequate,

- Facilitating tax amnesty procedures should encourage participation in amnesty,

- it must be clear that no other tax amnesty will be repeated in the future,

- The tax office should be equipped with advanced technology and serious and strict sanctions should be applied after tax amnesty (Abdurrahmani \& Doğan, 2019a, p. 1).

Rather than using the tax amnesty as a tool for collecting state revenues, it is imperative to make fundamental changes to Kosovo's tax system to avoid using the tax amnesty as an alternative means of collecting revenues. For this purpose, based on the information obtained from the explanations made in the theoretical part of the study, it would be more useful to carry out the following suggestions (Abdurrahmani \& Doğan, 2019b, p. 1921);

- Efforts should be made to expand the tax base to a reasonable level by lowering tax rates,

- Make tax laws simple and easy to understand, - The government should develop alternative policies to turn the informal economy into an ordinary economy,

- The effectiveness of tax audits must be improved,

- Measures should be taken against tax evasion,

- taxpayers' taxes are made according to their financial strength,

- Arrangements should be made to ensure that those who earn more pay more, while those who earn less pay less.

United States of America

Tax Amnesty has been carried out by many US states. According to available data, it is known that in Los Angeles raised $\$ 18.6$ million in 2009 and claims that the amount raised was $\$ 8.6$ million more than expected and that there were assets held at $\$ 6.7$ million. There was also the state of Louisiana which raised $\$ 450$ million in its tax amnesty program in 2009 . This figure is three times more than expected, according to Republican Governor at the time Bobby Jindal (Safri, 2015, p. 115).

The tax amnesty program has been implemented by more than half of the states in the United States. There are several states that are able to extract large amounts of income through the tax amnesty program. The state of New York raised \$401 million, and California, Illinois, and Michigan each raised more than $\$ 100$ million. While other states can be said to be not as successful as these states, such as North Dakota, Idaho, Texas, Kansas, and Missouri each were only able to raise less than \$1 million (Setiawan, 2007, p. 28).

\section{CONCLUSION}

The results of this study found that tax amnesty that is too prevalent will have a negative impact on taxpayer behavior. The predictable tax amnesty will cause tax evaders to delay paying their taxes until a future tax amnesty arises, thinking that it will provide them with the best tax rates. Based on the above analysis, several recommendations for a successful tax amnesty can be concluded: First, in terms of timeframe, it is not recommended that the government have a long-term tax amnesty program because it will damage the credibility of the government. Second, in terms of frequency, the government is not recommended to launch a tax amnesty program on a regular basis. Tax pardons that are too frequent will penalize the original taxpayer and encourage potential taxpayers to withhold tax payments and wait for the same scheme to be offered in the future. Third, the government is recommended to impose a progressive tax rate if the government often carries out a tax amnesty program so that tax evaders are more motivated to participate in the tax amnesty as soon as possible.

\section{REFERENCES}

[1] M. A. Ibrahim, R. Myrna, I. Irawati, and J. B. Kristiadi, “A Systematic Literature Review on Tax Amnesty in 9 Asian Countries,” Int. J. Econ. Financ. Issues, vol. 7, no. 3, pp. 220-225, 2017.

[2] J. Alm, J. Martinez-Vazquez, and S. Wallace, "Do Tax Amnesties Work? The Revenue Effects of Tax Amnesties During the Transition in the Russian Federation," Econ. Anal. Policy, vol. 39, no. 2, pp. 235-253, 2009.

[3] W. Leenders, A. M. Lejour, S. Rabaté, and van 't R. Maarten, "Offshore Tax Evasion and Wealth Inequality: Evidence from a Tax Amnesty in the Netherlands," SSRN Electron. J., pp. 1-39, 2020.

[4] R. Andrian, “Analisis Penerapan Tax Amnesty Dalam Rangka Meningkatkan Kepatuhan Wajib Pajak Dan Penerimaan Pajak,” Universitas Islam Negeri Syarif Hidayatullah Jakarta, 2016.

[5] A. D. Trifani, "Faktor-Faktor Yang Mempengaruhi Kemauan Wajib Pajak Dalam Mengikuti Program Tax Amnesty Dan Dampaknya Terhadap Tingkat Kepatuhan," Universitas Islam Negeri Syarif Hidayatullah Jakarta, 2018.

[6] L. N. Suryandari, "Analisis Hubungan Antara Persepsi Tax Amnesty Dan Persepsi Kepatuhan Wajib Pajak Orang Pribadi Studi Empiris di Kantor Pelayanan Pajak Pratama Magelang," Universitas Sanata Dharma Yogyakarta, 2017.

[7] Safri, "Efektifitas Program Tax Amnesty dan Faktor Keberhasilannya: Pembelajaran dari Negara-Negara yang Pernah Menerapkan,” N.D, pp. 105-120, 2015

[8] T. Tukina, "Tax Amnesty Role in Developing National Public Welfare," Humaniora, vol. 8, no. 3, pp. 271-277, 2017.

[9] M. K. Huda and A. Y. Hernoko, "Tax Amnesties in Indonesia and Other Countries: Opportunities and Challenges," Asian Soc. Sci., vol. 13, no. 7, pp. 52-61, 2017.

[10] N. Purnomolastu, "Comparison of Tax Amnesty Implementation in Developing Countries (Comparison Study of Tax Amnesty Implementation between Indonesia and India 2016)," J. Bisnis Terap., vol. 01, no. 01, pp. 77-86, 2017.

[11] I. Geraldina and R. Jasmine, “Tax Amnesty and Earnings Management: An Initial Evidence,” J. Din. Akunt., vol. 11, no. 1, pp. 26-33, 2019.

This publication is licensed under Creative Commons Attribution CC BY.

http://dx.doi.org/10.29322/IJSRP.11.08.2021.p11608

WwW.ijsrp.org 
ISSN 2250-3153

[12] E. S. Natania and A. Davianti, “An Accounting Perspective of Tax Amnesty in Indonesia,” J. Account. Audit. Bus., vol. 1, no. 1, pp. 1-18, 2018.

[13] F. P. Ibrahim, "Impact Of Tax Amnesty And Its Implication On Tax Collection In Tanzania: A Case Of Study Ilala Tax Region," Mzumbe University, 2020.

[14] J. Ahmed, "Effectiveness Of Tax Amnesty On Revenue Increase In Tanzania: A Case Of Large Taxpayers," Mzumbe University, 2020.

[15] A. Amersi, "A Comparative Study Of The Impending Implications Of The Kenyan Tax Amnesty On Ruminants Of Foreign Income," Kenyatta University, 2019.

[16] E. Abdurrahmani and Z. Doğan, "Required Practices for Successful Tax Amnesty: Kosovo Case Enis," J. Econ. Manag. Sci., vol. 2, no. 3, pp. 1-13, 2019.

[17] E. Abdurrahmani and Z. Doğan, "The Social, Economic and Fiscal Effects of Tax Amnesty the Evidence from Kosovo," Int. J. Manag. Excell., vol. 13, no. 2, pp. 1910-1921, 2019.

\section{AUTHORS}

First Author - Desy Farina, Graduate Student, Institut STIAMI Jakarta, desyfarina65@gmail.com

Second Author - Ghulam Fathul Amri, Graduate Student, Institut STIAMI Jakarta, ghulamzuhri@gmail.com

Third Author - Prianto Budi Saptono, Lecturer, Institut STIAMI Jakarta, prianto.budi@gmail.com

Correspondence Author - Ghulam Fathul Amri, ghulamzuhri@ gmail.com, +6285861900600 